\author{
L.S.GOLOVKOVA ${ }^{1}$, G.V. OMELCHAK ${ }^{1^{*}}$ \\ ${ }^{1 *}$ Department. "Finance and Economic Security", Dnepropetrovsk National University named railroad transport \\ academician V. Lazaryana, st. Lazaryana, 2, Dnepropetrovsk, Ukraine, 49010, tel. +38 (056) 373 15 04, Email. Mail \\ ganna_zp@ukr.net
}

\title{
KEY TERMS COMPETITIVENESS OF RAILWAY TRANSPORT UKRAINE UNDER ECONOMIC INSTABILITY
}

Purpose. Development of theoretical approaches and practical recommendations for evaluation of the methods and ways of organizing mechanism for managing the competitiveness of the railways of Ukraine, which contribute to stabilize the industry in a market economy transformation and economic instability. Methods. Reforming the rail transport today is the first step towards institutional adaptation Railway Transport of Ukraine and transparent use of market mechanisms. The first reform requires qualitative improvement of the legal framework and organizational structure, which requires a systematic, integrated approach. Results. The paper proposed areas of innovation, motivation innovative processes for rail transport innovation in rail companies that will increase the competitiveness of rail transport in the transport market and improve the competitive position in the development of interspecific competition. Scientific novelty. Organizational measures to improve the competitiveness of rail transport and the need for branch development potential as a competitive activity of railway transport, accompanied by the formation of vertically - integrated in the structure and maintenance of infrastructure. The practical significance. Our studies allow to say that nowadays the most important task railway complex of Ukraine to work in a volatile market economy is to provide a stable financial situation. In Ukraine, the railway infrastructure is for public funds. The current system of rail transport in Ukraine is a combination of railways and other public companies that do not actually executed in a single industrial complex with low attractiveness for investors and can not without government guarantees to attract the necessary investment in fixed assets. Given the above, you can ensure increased competitiveness of railway transport of Ukraine.

Keywords: innovation, competitiveness, potential rail

\section{Introducion}

Transport links altogether are the material base of development of economic activity of a state. They satisfy public interests in moving, bind the elements of the publicly-territorial systems in a single unit.

Nowadays the problems of competitiveness estimation and analysis of financial results are paid a lot of attention all over the world. In particular, there are well-known the works of such specialists as Goncharova E. V., Blank I. O., Dykan` V. L. [4], Kardyna O. G. [6], Savits `ka G. V., Sheremet A. D., etc. For the last five years this problem has been investigated by Golovkova L. S. [3], Korzhenevich I. P., Chornij V. V., Reshetnyak E. I, Vachevs`kyy M. V., Barash Y. S. [1], Pen`shyn N. V., Il`chuk V. P. [6].

In the conditions of reformation and instability of Ukrainian economy, during including the state into the system of international economic connection, the railway transport has to solve complex tasks of adoption of its functioning in the market conditions.

Except the general falling of transportation volumes, there appeared their redistribution between the different kinds of transport, first of all, for benefit of motor transport whose share of valuable export and import loads` transportations has grown.

In these terms the increase of competitiveness of the railway transport is vitally important. It needs to solve a great number of problems connected with the increasing the railway enterprises 'competitiveness such as bringing the capital assets, labor and material resources to conformity with the volumes of works and needs of economy and population in transportations, creation of flexible modern effective control consumer-oriented system, which can help to make scientific and technical progress, to increase the competitiveness of railway transport, to make its economic relations with consumers, state, related kinds of transport and the whole infrastructure more effective. 


\begin{abstract}
Aim
The aim of this work is to develop the theoretical approaches and practical recommendations to increase competitiveness level, to improve methods and ways of organization of the mechanism of running the railways competitiveness in Ukraine, which can assist to stabilize the branch in the conditions of eurointegration and instability of economy.

Methodology

During the process of research of competitiveness estimation, it is possible to mark the most objective result can be achieved by means of methods of complex estimation, which include determination of group and single indexes of railway transport s competitiveness in Ukraine. The mentioned methodology shows the necessity of work organization on the selection a lot of data, which does not guarantee reasonable conclusions about the competitiveness of all system.
\end{abstract}

\section{Results}

The railway transport of Ukraine is one of the basic kinds of transportations of the general use. It belongs to the State Administration of Railway Transport of Ukraine "Ukrzaliznytsia”. Structurally it is a single productive and technological complex including enterprises and establishments according to the productive and social intended purposes.

Railway transport takes the first place among all the kinds of transport in Ukraine according to goods turnover and passenger traffic. It plays an important role both in inner- and interstate connection to the long distances.

The Ukrainian railways have large potential in relation to freight transportations. The locations of Kyiv and other main cities assist railways, as transport facilities, in speed transportations between the biggest cities in Ukraine. The financial flows must be also better organized and more transparent.

The production and technological complex of railway transport is a difficult infrastructure, in itself, based on the railway network, which directly provides needs in transportations. In our time "Ukrzaliznytsia" unites the half-dozen of railways: the railways of Donetsk, L`viv, Odessa, Pivdenna
(Southern), Pivdenno-Zakhidna (Southwestern) and Pridniprovska Railways. "Ukrzaliznytsia” carries out over $80 \%$ cargo transportations in the country and approximately $50 \%$ of passenger transportations.

In the terms of total reformation of economy and the change of geopolitical status of Ukraine the necessity of reasonable transport policy, which would be able to take into account the transport area features and its role in economic and social life in the country, is clearly understood.

The economic crisis influenced most destructively the transport sector of economy. Thus, the volumes of a transport work since the last ten years decreased in 4.0 times along with all negative consequences and, moreover, the support of the processes of simple reproduction of capital assets went down in the area.

For the last days almost the rate of updating of the capital productive assets grew in 10 times short in the transport sector. As a result, the state of competitiveness of productive and technical base of railway transport became worse, the programs of its economic and social development are almost rolled up, and that creates a substantial threat to the reliable and safe functioning of railways.

In these terms the railway transport becomes the main brake of economy development in Ukraine, which needs the urgent solving all the problems connected with the support of its investment and innovative development and its competitiveness.

The analysis of transit traffics of goods through the territory of Ukraine in 2008-2013 due to all the types of transport (table. 1) shows that except the pipeline transport the volumes of transportations by railway transport include a greater part of goods traffics (87,9\% on the average for the period).

During the reviewed period there diminished the volumes of cargo transportations by railway transport by $59 \%$, which is partly related to the redistribution of such transportations on the motor transport.

Lately, the government of Ukraine has paid considerable attention to the questions of the realization and development of transit potential of the country, and today it is possible to see the realization of some practical measures in this direction which is very urgent for activation of the processes of eurointegration. 
Table 1

The dynamic of transit traffics of goods due to the kinds of transport, thus. tones [8]

\begin{tabular}{|c|c|c|c|c|c|c|}
\hline Performance & 2008 & 2009 & 2010 & 2011 & 2012 & 2013 \\
\hline Total (without pipeline) & 107154,2 & 101925,1 & 50152,4 & 52913,5 & 58123,5 & 47915,5 \\
\hline including \% & 100 & 100 & 100 & 100 & 100 & 100 \\
\hline Railway & 99882,4 & 93347,6 & 44834,6 & 44511,8 & 48669,5 & 40940,1 \\
\hline including \% & 93,3 & 91,6 & 89,4 & 84,1 & 83,7 & 85,4 \\
\hline Marine & 2694,0 & 3487,0 & 1899,4 & 3660,4 & 3912,1 & 1637,7 \\
\hline including \% & 2,5 & 3,4 & 3,8 & 6,9 & 6,7 & 3,4 \\
\hline Motor-car & 4494,6 & 4908,7 & 3354,2 & 4649,1 & 5011,2 & 4850,0 \\
\hline including \% & 4,2 & 4,8 & 6,7 & 8,8 & 8,7 & 10,1 \\
\hline Marine & 37,43 & 74,73 & 0 & 0 & 0 & 7,6 \\
\hline including \% & 0,0 & 0,1 & - & - & - & 0,0 \\
\hline Aviation & 1,3 & 1,5 & 1,2 & 1,6 & 2,8 & 3,0 \\
\hline including \% & 0,0 & 0,0 & 0,0 & 0,0 & 0,0 & 0,0 \\
\hline Other & 44,5 & 105,5 & 62,9 & 90,6 & 527,8 & 477,1 \\
\hline$\%$ & 0,0 & 0,1 & 0,1 & 0,2 & 0,9 & 1,0 \\
\hline
\end{tabular}

With the aim to increase the efficiency of market activity, it is necessary to conduct constantly the estimation of the competitiveness of railway enterprises on the base of economic, financial, technical and technological indicators.

For providing the effective functioning of railway industry, it is necessary to increase the level of its competitiveness continually. According to this, it is acceptable to distinguish next organizational measures (fig.1).

The character and depth of problems of the railway transport complex in Ukraine during the modern implementation of area`s transformations limit possibility of high-quality and appropriate imple-

The potential of the railway area should be treated as an ability and possibility to create new or to modernize the existent objects of the railways infrastructure, which will allow to improve their functioning and increase the social and economic efficiency of functioning of railway area entirely [7].

There should be defined the priority aims of potential development such as: mentation of strategically important investment and innovative projects. The current principles of functioning of the railway transport complex must be:

- the strategic vision of problems of the area and country and mechanisms of their solving;

- the greatest possible orientation on own potential, means of production, transparency of activity, backtracking from the shadow economy patterns of choosing the partners and contractors;

- the completeness of satisfaction of financial problems;

- the radicalism of changes of the financial, technical, organizational and administrative characters in accordance with the processes of eurointegration.

- the development of competences in the new types of engineering (first of all, high-speed highways);

- the international market entry and participation in the international projects of railway infrastructure engineering;

- the development of competences in the sphere of engineering and the management of large infrastructural projects; 


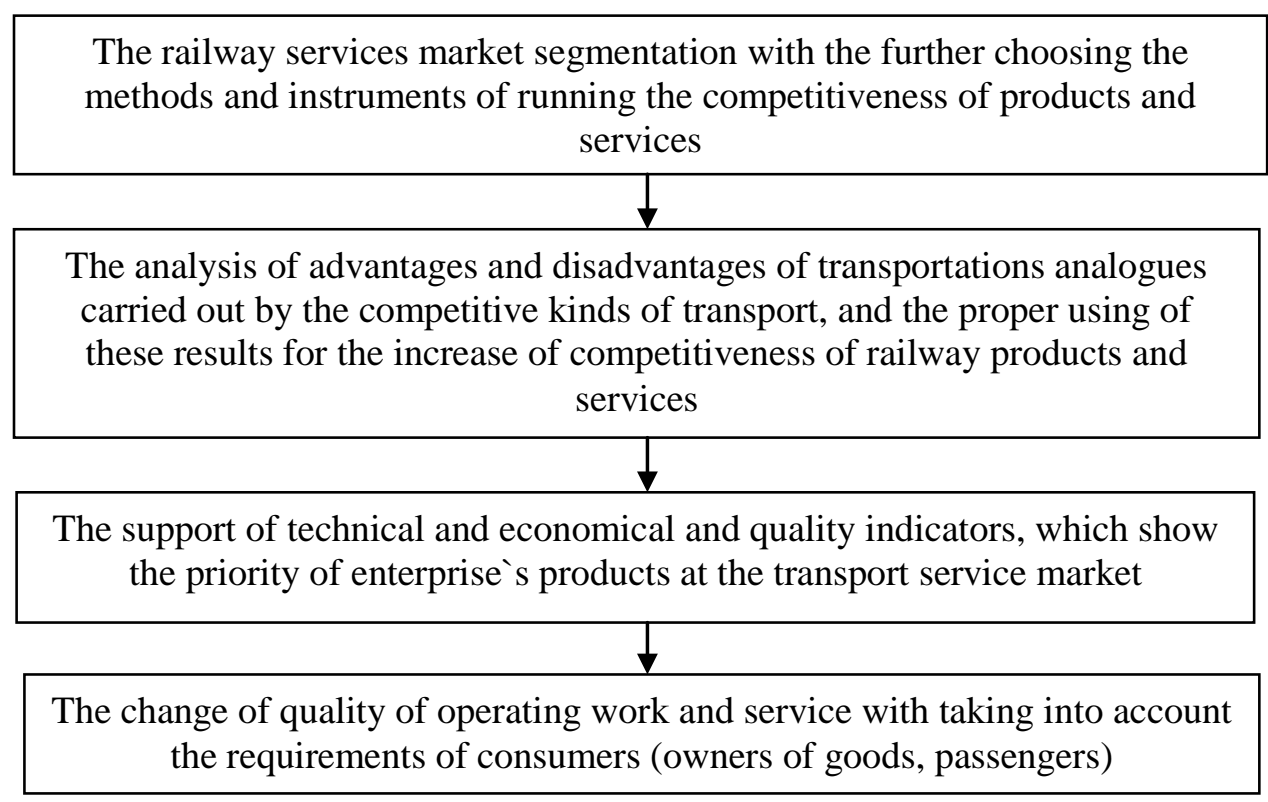

Fig. 1. The organization measures of the increasing the competitiveness level of the railway transport enterprises. Source: created by author

- the development of new technics and the introduction of innovative technologies and standards of engineering, the attraction of strategic investors to develop, update and diversificate the production facilities.

Thus, today there is a clear confidence at the necessity of separation of the potential development as a competitive type of activity of railway transport which is accompanied by forming vertical and integrated structure for the area and by reformation of the infrastructure objects.

In terms of intensive development of market relations in the country, the market of cargo transportations and of accompaniment services is actively forming. In connection with said above, the railway transport services, which can strengthen the positions of the transport sector and positively influence on the general economic result and the competitiveness, are of considerable character.

Nowadays the railway transports works with the capital assets, the wear of which is considerable enough and presently is more than $55 \%$ in the area [8]. In these terms the task of estimation of the property and financial potential of railway transport enterprises is of great importance.

The property potential of the railway transport is a base of performance of the transportation work and gains purposeful changes during the reformation.
The management of the property potential in the long term must be effective, based on system approach and carried out from the positions of increasing the competitiveness of railway transport in the market environment.

However, the irrational structure of capital productive assets and of circulating assets, the low rates of updating can result in worsening the market activity of the enterprises and decline the competitiveness of railway enterprises.

The reliable estimation of the cost of the property complex will allow not only to define the real financial position, but also to form investment resources more reasonably and optimize tax payments.

In the modern market conditions the railway enterprises must lead an active innovative policy, thus, getting in such a way the considerable competitive advantages, creating new consumer values providing the simultaneous cost cutting. Such competitive advantages can be: non-material assets which are the results of scientific, research and design-engineering work; patents; organization of new technological processes etc.

The increases of efficiency of functioning and the strengthening of competitive activity can result in actualization of the innovative processes. Innovative processes become a major part of running in the market conditions. At the same time the inno- 
vative activity is oriented not on needs and possibilities of enterprises as producers of goods and services, but on needs of the market.

The problem of forming the innovative potential as a necessary element of the reorientation of economic processes, which must be activated on the railway transport, is difficult and many-sided.

Primarily, it is because of the fact that the process of creation of the innovative system takes place in the conditions of the difficult unstable economic situation in Ukraine and the eurointegration without the sufficient financial support. Thus, it is necessary to provide the innovative policy, which is oriented on forming the stable potential for the future increase and, as a result, increase of competitiveness of railway enterprises in the conditions of the eurointegration changes.

Thus, the system of the innovative transformations to the context of the eurointegration must provide not only the effective functioning of enterprises of railway transport, but also high competitiveness of railway transport at the market of international transport services. The influence of the current innovative processes, which must be activated at a railway enterprise, influence its market value, can be estimated in the profitable way of evaluation of the property complex.

The financial potential of an enterprise is an aggregate of its financial resources, which it owns, of its competences and capabilities of its employees to carry out an effective financial management with the aim of achieving the maximally useful effect. Generally, the task of estimation and creation of the financial potential is formulated as a task of estimation of accordance of his possibilities with the selected competitive strategy. Nowadays the financial potential can be described as:

- the real possibilities of an enterprise (realized and unrealized in some sphere of economic activity);

- the volume of the resources and reserves of an enterprise - attracted and not attracted in productive activity.

The financial potential of a railway enterprise represents the level of his competitiveness. The competitiveness can be determined as a comparative description of its financial potential which contains the complex estimation of the state of its main parameters in relation to standards (due to the world, national, branch ones, other enterprise).

One of the most important task of railway complex`s work in Ukraine in the conditions of unstable market economy is providing the stability of its financial state. Stable financial position of an enterprise is characterized by its capital growth by means of the own and loan funds, which can be achieved by high productive results and economic efficiency of the using resources.

With the aim of estimation and description of financial potential it is necessary to make permanent monitoring, which allows to take into account general economic tendencies and changes in a public economic policy. In the conditions of market economy the main feature of financial and economic activity of railway complex is business and financial solvency. If an enterprise is financially stable, it can give competitive advantages to it to attract investments, credits, to choose suppliers, select skilled staff, and it makes an enterprise competitive one in the market sector.

In a period of reformation of the area the basic task is to use scientific, productive and administrative potentials and potential of safety effectively. The world railway transport system is one of the most developed and in the context of eurointegration the main task is an effective reformation of Ukrainian railway transport infrastructure with the aim of its updating and increasing the level of its competitiveness in order to make it a full member and partner of the world multinational corporations.

The increase of work efficiency of railway transport in Ukraine should be based on the intentional scientifical and technical policy in the area.

It is necessary to focus on scientific potential of railway industry due to the researches including the next main directions:

- resource-conscious production technologies;

- introduction of high-speed passenger railway transportations;

- development of telecommunications and informatizations;

- introduction of hardware of new generation;

- improvement of technology of transportation process;

- support of increasing the efficiency of financial and economic activity of transport;

- increasing the safety of motion;

- solving the ecological problems;

- improvement of labor terms and safety etc.

During realization of innovative policy of the area the structure of railway infrastructure is of great significance. 
The innovative activity of railway transport must be run due to such priority directions as:

- cutting of operating costs by creation and introduction of more effective economic technologies and improvement of basic normative technological documents;

- automation of basic technological processes;

- modernization of hardware at the stations;

- improvement of labor terms and safety;

- creation of the mechanized complexes for repair and maintenance of railway tracks and engineering building;

- forming of the diagnostics system of railway tracks and engineering building;

- development of technical measures for the system of running the railway enterprises by the means of resource-conscious production technologies;

- realization of technical measures for updating resources of operating engineering building [10].

There are such important problems of the innovative policy in the sphere of commercial work of railway transportations as: creation of resourceconscious production technologies, improvement of the system of freight tariffs, creation and introduction of the complex of CASS of management, new hardware and technologies.

The main tasks of the innovative policy in the sphere of passenger transportations must be: development and production of passenger rolling stock of new generation, creation and introduction of new products of passenger transportation service. Creation of carriages of new standards, which can guarantee high safety and comfort of a trip, must be a base of these works.

\section{Scientific and practical meaningfulness}

There are shown the problems of practical estimation of competitiveness of railway enterprises in Ukraine, which underline the necessity of complex estimation of the activity of the enterprises and the direction of the practical use for analytical work in the article.

The conducted

The researches made enable to assert that nowadays the major task of railway complex in Ukraine in the unstable market economy conditions is to provide the stable financial state. In Ukraine the railway infrastructure are supported by the government facilities. The existent system of railway transport in Ukraine is the aggregate of railways and other state enterprises which actually are not formed into a single productive complex and have a low attractiveness for investors that does not allow without a state guarantee to attract necessary investments in updating of the fixed assets. The necessity of separation of development of the potential as a competitive type of activity of railway transport is offered here with a help of forming vertically-integrated structure in the area and repairing its objects.

\section{Conclusions and prospects of further researches}

A railway transport has a high enough technical and technological potential. At the high level of wear of the fixed assets at the Ukrainian railways, however, the infrastructure of major directions is powerful enough. The projects set below to realization have high efficiency and under effective and reasonable management they will give a positive effect.

Development of the innovative activity, motivation of innovative-investment processes at the railway transport, implementation of innovations in work of railway companies can help to increase the competitiveness of railway transport at the market of international transport services and to improve competitive positions in terms of the eurointegration processes and high competition.

The major task of railway complex in Ukraine during work in such conditions of unstable market economy is to provide the stable financial state. In Ukraine the financial support of railway infrastructure is given by the government. The existent system of railway transport in Ukraine is the aggregate of the railways and other state enterprises which actually are not combined into a single productive complex and have a low attractiveness for investors and it does not allow without a state guarantee to attract necessary investments into updating the fixed assets and provide the eurointegration processes.

The reformation of the system of railway transport today is the first step to institutional adaptation of railway transport in Ukraine, and also to use of transparent market mechanisms. The first thing the reformation requires is the high-quality improvement of legislative base and of organizational structure. For this there should be used the complex system approach, updating the management and further improvement of the area functioning. 


\section{REFERENCES}

1. Office of the country by rail: 2nd ed., Overhauls. and add / J.S. Barash. - Dnepropetrovsk, 2006 $259 \mathrm{p}$.

2. Theoretical and methodological components of Railway Transport of Ukraine / O. Dejneka, L.A. Pozdnyakov // Bulletin of Economics and transport industry. - 2008. - № 25. - S. 62-65.

3. The total economic potential of the corporation: the formation and development: Monograph / L.S. Golovkova. - Kiev: Izd CPU, 2009 - 340 p.
4. DicanyaV.L. Ensuring the effectiveness of innovation of railway Monograph / V.L. Dikan, V.A. Zubenko. - H .: UkrDAZT, 2008 - 194 p.

5. Innovation - investment of railway transport: Establishment and Development / V.P. Il'chuk. - K .: Logos, 2004 - 381s.

6. Kirdina O.H. Methodological aspects of investment - innovative development of the railway sector of Ukraine: Monograph / O. Kirdina. - $\mathrm{H}$.: UkrDAZT, 2011 - 312 p.

7. Problems and main directions of railway reform Ukraine / Y.M. Tsvyetov, M. Makarenko, M.Y. Tsvyetov et al. - K .: KUETT, 2007. - 222 p.

8. http://www.ukrstat.gov.ua

\section{Л.С. ГОЛОВКОВА ${ }^{1}$, Г.В. ОМЕЛЬЧАК ${ }^{1 *}$ \\ $1^{1 *}$ Каф. «Фінансів та економічної безпеки», Днепропетровский национальный университет железнодорожного транспорта имени академика В. Лазаряна, ул. Лазаряна, 2, Днепропетровск, Украина, 49010, тел. +38 (056) 373 15 04, эл. почта : g.liudmila@mail.ru ; ganna_zp@ukr.net \\ ЗАБЕЗПЕЧЕННЯ КОНКУРЕНТОСПРОМОЖНОСТІ ЗАЛІЗНИЧНОГО ТРАНСПОРТУ УКРАЇНИ В УМОВАХ СВРОІНТЕГРАЦЇ̈}

Мета. Розробка теоретичних підходів і практичних рекомендацій щодо оцінки рівня конкурентоспроможності, методів та способів організації механізму управління конкурентоспроможністю Залізниці України, що сприятиме стабілізації галузі в умовах нестабільності економіки та євроінтеграції. Методика. Реформування системи залізничного транспорту сьогодні є першим кроком на шляху інституційної адаптації залізничного транспорту України до викликів глобалізаційного простору, євроінтеграційних процесів, а також необхідності застосування прозорих ринкових механізмів. У першу чергу реформування вимагає якісного удосконалення законодавчої бази і організаційної структури, для чого необхідний системний та комплексних підхід. Результати. У роботі запропоновані напрями розвитку інноваційної діяльності, мотивації інноваційних процесів на залізничному транспорті, впровадження нововведень в роботу залізничних компаній, що дозволить підвищити конкурентоспроможність залізничного транспорту на ринку міжнародних транспортних послуг і поліпшити конкурентні позиції в умовах загострення конкуренції. Наукова новизна. Запропоновано організаційні заходи щодо підвищення рівня конкурентоспроможності залізничного транспорту та необхідність відділення розвитку потенціалу як конкурентного виду діяльності залізничного транспорту, що супроводжується формуванням вертикально - інтегрованої структури в галузі та реформування об'єктів інфраструктури. Практична значимість. Проведені дослідження дають змогу стверджувати, що в сучасних умовах найважливішим завданням залізничного комплексу України при роботі в умовах нестабільної економіки та векторів євроінтеграції є забезпечення стійкого фінансового стану. В Україні підтримка залізничної інфраструктури відбувається за державні кошти. Існуюча система залізничного транспорту в Україні є сукупністю залізниць та інших державних підприємств, які фактично не оформлені в єдиний виробничий комплекс, мають низьку інвестиційну привабливість i не дозволяють без державної гарантії залучати необхідні інвестиції в оновлення основних засобів та впровадження інновацій. Враховуючи вищезазначене актуалізуються питання щодо формування напрямів та умов забезпечення конкурентоспроможності залізничного транспорту України в конттекстієвроінтеграції.

Ключові слова: євроінтеграція, інновація, конкурентоспроможність, потенціал, залізничний транспорт. 


\section{Л.С. ГОЛОВКОВА ${ }^{1}$, Г.В. ОМЕЛЬЧАК ${ }^{1 *}$}

${ }^{1^{*}}$ Каф. «Финансов и экономической безопасности», Днепропетровский национальный университет железнодорожного транспорта имени академика В. Лазаряна, ул. Лазаряна, 2, Днепропетровск, Украина, 49010, тел. +38 (056) 37315 04, эл. почта ganna_zp@ukr.net

\section{ОСНОВНЫЕ УСЛОВИЯ ПОВЫШЕНИЯ КОНКУРЕНТОСПОСОБНОСТИ ЖЕЛЕЗНОДОРОЖНОГО ТРАНСПОРТА УКРАИНЫ В УСЛОВИЯХ НЕСТАБИЛЬНОСТИ ЭКОНОМИКИ}

Цель. Разработка теоретических подходов и практических рекомендаций по оценке уровня конкурентоспособности, методов и способов организации механизма управления конкурентоспособностью железными дорогами Украины, которые способствуют стабилизации отрасли в условиях рыночной трансформации экономики и нестабильности экономики. Методика. Реформирование системы железнодорожного транспорта сегодня является первым шагом на пути институциональной адаптации железнодорожного транспорта Украины, а также применение прозрачных рыночных механизмов. В первую очередь реформирование требует качественного совершенствования законодательной базы и организационной структуры, для чего необходим системный, комплексных подход. Результаты. В работе предложены направления развития инновационной деятельности, мотивации инновационных процессов на железнодорожном транспорте, внедрение новшеств в работу железнодорожных компаний что позволит повысить конкурентоспособность железнодорожного транспорта на рынке транспортных услуг и улучшить конкурентные позиции в условиях развития межвидовой конкуренции. Научная новизна. Предложены организационные мероприятия по повышению уровня конкурентоспособности железнодорожного транспорта, и необходимость отделения развития потенциала как конкурентного вида деятельности железнодорожного транспорта, сопровождается формированием вертикально - интегрированной структуры в области и ремонта объектов инфраструктуры. Практическая значимость. Проведенные исследования позволяют утверждать, что в современных условиях важнейшей задачей железнодорожного комплекса Украины при работе в условиях нестабильной рыночной экономики является обеспечение устойчивого финансового состояния. В Украине поддержка железнодорожной инфраструктуры происходит за государственные средства. Существующая система железнодорожного транспорта в Украине является совокупностью железных дорог и других государственных предприятий, которые фактически не оформлены в единый производственный комплекс, имеют низкую привлекательность для инвесторов и не позволяет без государственной гарантии привлекать необходимые инвестиции в обновление основных средств. Учитывая вышесказанное можно обеспечить повышение конкурентоспособности железнодорожного транспорта Украины.

Ключевые слова: инновация, конкурентоспособность, потенциал, железнодорожный транспорт 